\title{
Lexical Borrowing in Tourism Terminology
}

\author{
Yakubova Noira1, Musayeva Surayyo ${ }^{2}$, Norkhodjayeva Muborak ${ }^{3}$, Saidrasulova Shakhnoza ${ }^{4}$ \\ ${ }^{1}$ Teacher, Uzbek State World Languages University \\ ${ }^{2}$ Teacher, Uzbek State World Languages University \\ ${ }^{3}$ Teacher, Journalism and mass communication University of Uzbekistan \\ ${ }^{4}$ Teacher, Journalism and mass communication University of Uzbekistan
}

\section{ABSTRACT}

The article studied borrowing in replenishing the terminology fund of the tourism sector showed that it was most widely used in the Uzbek language, and most of the terms are borrowed from the English language, which can be attributed to the typological line of the Russian language. The predominance of English terms in Uzbek and Russian terminology is explained primarily by extralinguistic factors: the development of the tourism sector takes place with an orientation towards foreign experience, and tourism as a branch of the economy is highly developed in English-speaking countries, therefore the terms serving it are anglicisms that are most universal and meet the needs of this moment of development of the tourism industry.

\section{Key words}

vocabulary, borrowing, terminology, tourism industry, English-speaking countries, terminology, science, the problem of borrowing.

\section{INTRODUCTION}

Borrowing foreign language vocabulary attracts the constant attention of linguists and term scholars. This interest does not wane, since borrowing is, on the one hand, a source of replenishment of the vocabulary of the language. On the other hand, they form an integral part of the terminology systems of many fields of knowledge. When studying this method of replenishing the lexical composition of terminology, it is necessary to solve the question of what is meant by borrowing.

\section{LITERARY REVIEW}

The phenomenon of borrowing has been widely studied by both domestic and foreign scientists. A particularly keen interest in the problems of borrowing has been discovered since the mid-60s of the XX century, many scientific linguistic works appear in which various aspects of the borrowing process are considered. N.S. Avilova, S.A. Belyaeva, L.P. Krysin, Z.I. Lomakina, A.V. Mirtov, N.M. Shansky and others successfully resolved issues related to foreign language vocabulary. Nevertheless, in modern linguistics there is no unity in the interpretation of basic concepts, processes that relate to the movement of language elements from one system to another. Borrowing refers to the result of the influence of another language (O.S. Akhmanov), and the process of moving language elements from one language to another (L.P. Krysin). In this study, borrowing refers primarily to a word or phrase transferred from one language to another as a result of language contacts, and has been assimilated in a new language environment.

A comparison of tourist terms in Uzbek, Russian and English allows us to find that lexical borrowings of the Uzbek sample are much higher 
than borrowings of the English corps: $60.3 \%$ (422 units) and $6.3 \%$ (62 units), respectively. This difference in the quantitative ratio can be explained by the fact that in the terminology of tourism of the Uzbek language in recent years, due to the fast and dynamic developed tourism industry in Uzbekistan, borrowed concepts have become especially widespread, as a result of which a language vacuum has formed in the nomination of new concepts that are not familiar before. To denote the new concept of tourism, in most cases, a terminological unit of English-speaking origin is chosen, since the formation of the tourism industry in our country takes place using foreign, mainly American and Western experience.

\section{MATERIALS AND RESULTS.}

Therefore, the active borrowing of Anglicisms as one of the most productive methods of terminology in the "tourism" terminology system seems to be an obvious fact. In English, the main donor language is French. Most French terms nominate the concepts of the catering industry (entree, тепu, plat dujour, table d'hote menu, sommelier, a la carte menu, bistro, banquet, buffet) и индустрии гостеприимства (hotel, concierge, maitre d'hotel, suite, porter, apartment).

Here are examples of borrowing from other languages: Spanish (posada, cafeteria, cabana, parador, patio, siesta), Italian \{carnival, regatta, pizzeria, casino, studio), dutch (snack, cruise), swedish (smorgasbord). It should also be noted that some tourist terms contain Latinisms: sanatorium, condominium, museum, oceanarium, ad hoc, terminus, visa. Uzbek tourism terminology borrows terms mainly from the English language. At the same time, it is important to note that in $20 \%$ of cases English acts as an intermediary language, i.e., before entering the Uzbek language, the terminological unit passes from one language to English and only then to Uzbek, thereby forming a borrowing trajectory, for example: анимация (uzb.) - animation (eng.) - animationem (lat.); yapmep (uzb.) - charter (eng.)- A chartre (fr.); трансфер (uzb.)- transfer (eng.) - transferre (lat.); бунгало (uzb.) - bungalow (eng.) - bangla (hindu); хостел (uzb.)- hostel (eng.) - hostel (fr.).

We will give examples of loans from other languages: French (cabaret, buffet reception, restaurant, baggage, apartment, booklet, voyage: board, boarding house, passenger), Spanish \{cafeteria, patio, siesta), Italian (carnival, casino, carousel, salon, tavern), Dutch (flight, cabin), German (resort, freight, agent, route).

A large number of borrowed terms, especially Anglicisms, in Uzbek tourism terminology are due to a number of reasons. Many researchers note mainly within the linguistic factors of borrowing [Krysin, Breiter, etc.]. With regard to the Uzbek terminology system "tourism," the following internal reasons can be distinguished:

1. Lack of a corresponding concept/name in the cognitive base of the receptor language: Inclusive Tour - the main type of individual or group tour. As a rule, represents the trip which is strictly planned along a route, time, term, set and quality of services which is on sale to the consumer as the goods, inseparable on elements, at the total price which are usually including cost of both service, and driving through a route $[16,106]$; Parasailing - skiing with a parachute, which is tied by a cable to a motor boat $[14,298]$; package tour - any tour (individual or group) that includes a set of services (transportation, accommodation, meals, excursions, etc.), the total sales value of which is equal to the cost of its elements [13, 69]; transfer (transfer) - any transportation of the tourist inside the tourist center (delivery from the station, airport or seaport to the hotel and back; from one station, airport or seaport to another; from the hotel to the theater and back, etc.) $[17,355]$; hostel (hostel) - a type of hotel with a small set of services $[16,314]$.

2. The need to specialize the concept. This group of borrowings can include borrowings whose semantic role is different from the previously used term. So, for example, for what is now referred to in the field of tourism by the word "tour," the name "journey" has long existed. However, these words 
cannot be called synonyms: the term "tour" is more specific in meaning, since it means not just travel, but specifies it: it is a journey consisting of a complex of services (transportation, hotel accommodation, excursions, transfers, meals) [16, 84].

3. The desire to save language money when one borrowed word is used instead of a descriptive turnover. This reason for borrowing is closely related to the first, since, on the one hand, the speaker saves speech effort, and on the other, the language involves filling some lacuna with a nomination. For example, timeshare is the purchase of the right to use a number for a certain period of time in a hotel (boarding house, apartments) for a long period, and as a rule, conditions for exchange are created, which allows timeshare owners to change recreation places $[3,277]$. Anglicism in this case calls a new phenomenon, and at the same time replaces the cumbersome descriptive turnover.

The studied language material shows that most borrowings in the terminology system "tourism" in the Uzbek language $(62.1 \%$ of the total number of borrowed terms) and all borrowings in English relate to direct borrowings in which the material form of the word and its meaning are borrowed. At the same time, a foreignlanguage word passes into the receptor language using: - transliteration - a letter-by-letter transmission of a foreign-language word (parking/parking - a place for parking [2, 361]; rafting/rafting - traveling in the form of an alloy on a raft along a fast river [2, 481]; hostel/hostel - a type of hotel with a small set of services [14, 314]; chalet / chalet - a wooden dwelling with a sloping roof and widely overhanging eaves, common in Switzerland and other Alpine regions [4, 53]; cabaret / cabaret - entertainment given in a restaurant or club [4, 43]);

- transcription - sound transmission of the borrowed word \{reception/reception - reception [2, 178]; catering I catering - providing food and drinks outside the cafe or restaurant accommodation [9, 21]; chateau/chateau - the name of a country castle or a large country house in France; a variety of expensive and especially prestigious French hotels [2, 194]; smorgasbord / smorgasbord - Swedish buffet of many cold dishes $[4,286])$. In addition to literal borrowings, the group of direct or actual borrowings can also include transformed ones, which are formed by additional word-forming processes:

- suffixations - re-registration of a foreign suffix into a suffix used in the receptor language with a similar meaning (attraction/attraction attraction [9, 4], recreation/recreation - rest, restoration of physical and spiritual forces of man [17, 311], removal/destination - destination [2, 45], porter /porteur - somebody who carries luggage for travellers at an airport, a railway station, in a hotel [14, 268], leisure / leisir - the time remaining after work, travel to and from work, sleep and necessary personal and household tasks, i.e., 'discretionary time', which may be put to various uses, including travel and tourism [8, 104]);

- lexicalization - the formation of a single word from the phrase s smoke-free/duty-free - a duty-free trading system at airports, on the boards of aircraft, ferries and other vehicles, or in certain places of visiting foreigners [3, 78]; package tour/package tour - any tour that includes a set of services (transportation, accommodation, catering, excursions, etc.), the total sales value of which is equal to the cost of its elements [2, 221]).

\section{DISCUSSION}

It should be noted that transformed direct borrowings, as well as borrowings transmitted using transcription, are more characteristic of the Uzbek language than English, since many lexemes of English terms go back to Latin roots, which, naturally, are assimilated in English more fully and form the basis of many words of general nontheological use. In other words, many "aliens" forms for the Uzbek language are "their own" for English. Also, in the Uzbek language we identified words based on borrowed roots: 
- derivatives of borrowed words \{tour tourist, tourist; charter - charter; resort - resort; banquet - banquet);

- phrases with borrowed words (complex tour, direct charter, tabledot menu, outgoing tour operator, youth hostel, private transfer). In the group of borrowings themselves, such units noted in the Uzbek corps as foreign-language inlays should be especially noted. This term was first introduced by A.A. Leontiev to refer to foreignlanguage words functioning both outside the Russian language system and included in it as ordinary borrowings [7, 62-67]. This understanding of foreign language is capacious in nature and encompasses a wide range of phenomena. According to another, narrower definition, foreignlanguage inlays are considered as linguistic phenomena of a foreign language borrowed by the Uzbek language while preserving their foreignlanguage appearance, often in the graphic form of a source language [5, 54 - 57].

Y.T. Listrova emphasizes that, being outside, foreign-language lexemes are not borrowed, but used vocabulary of a foreign language in native speech, unlike vocabulary of foreign-language origin, are not facts of the language, are not included in its vocabulary and therefore, as a rule, are not reflected in dictionaries $[6,132]$. Based on the classification of Yu.T. Listrova, we identified the following subgroups of foreign language embossments in terminology: 1 . Contaminated or foreign-lingual stints. During the study, 7 such units were identified, which form various terms: call center, room service, wellness complex, SPA center, VIP transfer, event brand, lifestyle hotel. It should be noted that a single spinin may form multiple terms. For example, SPAspinning can be found in the following terminology units:

- (from hotel description) Elegant villas of coastal and water category are created for Nega and bliss. Services of SPA by Mandara high-end SPA Center. An important component is that the hotel has Russian-speaking staff [11, 24.08.2010];
- It is worth paying attention to the SPA complex, which offers unique procedures for the face and body, necessary for the beauty and health of the skin [11, 15.06.2010];

- (from the listing of the services provided by the hotel) one Spa-procedure as a gift (per adult once a week) [11, 15.07.2010];

VIP embedding is involved in the formation of the following terms:

- The hotel received the AAA Five Diamond Award for its professional approach to receiving guests, including organizing a VIP transfer from the airport, a Bamboo restaurant and access to two local golf courses [10, 14.07.2010];

- The hotel has four VIP rooms with TV, beds with bed linen and own patios [10, 14.07.2010];

- MITS Marketing Director Maria Fatyushchenko shared with the agency's useful information and news of non-binary VIP holidays in various regions of Italy, from Piedmont and Umbria to Sicily [11, 06.07.2010];

- To be a VIP-member of Musenides Travel profitable and honorable: our clients later become our partners and friends, who from year to year enjoy all the advantages and privileges of their position [10, 25.08.2010];

2. Full inlays, i.e. inlays inserted into speech without change. During the analysis of tourist texts, we found a fairly large number of complete embossments $19 \%$ of the total number of borrowings themselves):

Further, with the all-inclusive system, Aldemar hotels invite to the world of exquisite tastes and offer their guests several times a week at no extra cost to visit a la carte restaurants, and all imported drinks will be offered in bars [11, 04.08.2010]; now, in the hot summer season, the palm tree among the maritime resorts of France holds, of course, the Cote d'Azur. Our fellow citizens are increasingly liking category 4-5* hotels, as well as non-standard accommodation (junior suite, suite rooms) [11, 15.07.2010]; Thanks to good accommodation options, Ultra AllInclusive system, stunning shows and Greek 
evenings, guests of the hotel will spend unforgettable days of their vacation [11 19.05.2010]; Lotte has created more than 400 jobs in Moscow for young hospitality professionals. The personnel training system adopted in all companies of the Lotte group provides for a qualitatively new level of organization of relations with the client and brings to the fore service mind [12, 12.05.2010];

It should be especially noted that when determining foreign-language embossments, the adaptation parameter - development - is put first by linguists. The main functional parameters of the use of this term are related to the alien nature of the material. The use of foreign-language embossments is accidentally, always contextbound, usually accompanied by text-based means of highlighting information and explanations; they are not recorded in dictionaries. Moreover, the use of foreign language embossments can only be understood by a person skilled in the art.

Indirect borrowing enters the language by means of calking, in which a restructuring of receptor language models occurs, resulting from the introduction of foreign-language elements into the spheres of the language, which are characterized by a high structural organization [Weinreich, 1972]. An analysis of Uzbek terms in the tourism sector showed the presence of syntactic cripples in the sample. Syntactic mapping refers to the transfer of the structure and meaning of foreignlanguage phrases, abbreviations and other syntactic constructions by means of the native language: American plan/American plan -hotel rate, which includes the cost of accommodation and three meals a day [2, 485]; caravan tourism is a type of car tourism in which a self-propelled or carattached van $[3,153]$; full boarding/full board way in hotels, which includes three or four meals a day.) $[16,205]$. In the Russian sample, the number of syntactic cripples is $33.9 \%$ of the total number of terms borrowed. As some scholars rightly believe, calking is most pronounced in languages where derivation and vocabulary are particularly developed $[15,65]$. Due to the fact that word- formation processes are quite developed in the Uzbek language, it is considered the most susceptible to calcination. The third group of borrowings in our classification of borrowed tourist terms are hybrid entities. The term "hybrid formations" was first introduced by E. Haugen, by which he meant words partially consisting of foreign-language elements (loan blends) [Haugen, 1972]. Such derivatives and complex words arise from the "morphematization" of foreign-language elements, that is, the inclusion of borrowed morphemes in the processes of word formation of the borrowing language.

Also, such borrowings were called semisharks (the term was first used by L.A. Bulakhovsky) or semi-borrowings. Among the Uzbek terms of the tourism sector, $4 \%$ of hybrid formations (17 terms) were found: camping parking, wellness center, lounge zone, guide translator, premium class, reception cocktail. When moving to the receiving language, the borrowed term goes through the stage of assimilation or assimilation. The problem of mastering foreign language terms of borrowing in the receptor language is complex and multifaceted. Language learning is a diachronic process in which, on the one hand, the connections and relations of two language systems are intertwined, and, on the other hand, the connections and relations existing within the language-receptor system.

\section{CONCLUSION}

In general, the analysis showed that most borrowings of the "tourism" terminology system go through two stages of adaptation to the Uzbek language system: "entry" into the receiving language (phonetic and graphic level) and the actual mastery of the borrowed term by the receiving language (semantic level). Summing up the lexico-semantic analysis of tourism terminology, it should be noted that, on the one hand, it is at the lexical level that the more mature state of English terminology of the tourism sector and the emerging state of Uzbek are observed. On 
the other hand, recently there has been a tendency towards parallelism in the lexical and semantic processes of English and Russian. The most obvious such "mirror reflection" is manifested in methods of semantic derivation and borrowing. Thus, it can be stated that tourism terminology is characterized by the internationality of its components, which is primarily associated with globalization processes, which have led to a convergence of conceptual and terminological systems, that is, the emergence of some part of terminology common to both languages.

\section{REFERENCES}

1. Beaver A. A Dictionary of Travel and Tourism Terminology. Second edition. Oxon: CABI Publishing, 2005. - 395 p.

2. Big Glossary of Terms of International Tourism/Ed. M.B. Birzhakova, V.I. Nikiforova. - St. Petersburg: Publishing House "Gerda," 2006.-936 p.

3. Collin P.H. Dictionary of Hotels, Tourism and Catering Management. Teddington: Peter Collin Publishing, 1994. - 348 p.

4. Dictionary of Leisure, Travel and Tourism. Third edition. London: A\&C Black Publishers Ltd, 2006. - 378 p.

5. Kameneva L.N. On the transfer of foreign language expressions in German texts when translated into Russian//Issues of scientific and technical translation. - Chelyabinsk, 1978. - P. $54-57$.
6. Listrova Yu.T. Foreign-system language embossments in Russian fiction of the XIX century. - Voronezh: Publishing House of Voronezh State Uns, 1979. - 155 p.

7. Leontiev A.A. Foreign language inlays in Russian speech//Questions of the culture of speech. - 1966. - No. 7. - P. 62 - 67.

8. Medlik S. Dictionary of Travel, Tourism \& Hospitality. Third edition. Oxford: Butterworth-Heinemann, 2003. - 283 p.

9. Prostakov I.V. Foreign terms in the turbo business: Short explanatory dictionary. - M.: Finance and statistics, 2008. - 128 p.

10. RATA-news. VIP tourism (2009-2010)

11. RATA-news (2004-2010)

12. RATA-news. Hotel \& Resort (2007-2010)

13. Ryabova I.A., Ismaev D.K., Putilina S.N. Dictionary of international tourist terms. - M.: Knigodel LLC: MATGR, 2005.-466 p.

14. Senin B.C. Tourism: mini-dictionary. - M.: Finance and statistics, 2004. - 64 p.

15. Sorokin Yu.S. The development of the vocabulary of the Russian literary language in the 30-90s of the XIX century. - M.-L.: Uchpedgiz, 1965. - $565 \mathrm{p}$.

16. Tourism, hospitality, service: Dictionarydirectory/G.A. Avanesova, L.P. Voronkova, V.I. Maslov, A.I. Frolov; Ed. L.P. Voronkova, -M.: Aspect Press, 2002. - 367 p.

17. Zorin I.V., Kvartalnov V.A. Encyclopedia of Tourism: Directory. - M.: Finance and Statistics, 2003. - 368 p. 